\title{
If the State provided free computer literacy, would it find takers? Evidence and propositions from the Akshaya project in India
}

\author{
Joyojeet Pal
}

Published online: 25 April 2009

(C) The Author(s) 2009. This article is published with open access at Springerlink.com

\begin{abstract}
The Akshaya project from Kerala has been a much discussed case for the community of practitioners and scholars working on technology and development. A unique feature of the project is its state-wide e-literacy goal in which one member of every household was trained in the telecenters set up under Akshaya at public expense. Using a survey of 1,750 households in the experimental area of Malappuram and a comparison group of neighbouring Kozhikode, this work investigates the extent of e-literacy and discusses the performance of service delivery using telecenters. While the question of whether public funds should be spent on projects such as telecenters or e-literacy continues to be an ongoing debate, the evidence here is that even though structural factors such as service delivery mechanisms and publicity make an impact on technology adoption, the overall participation in free e-literacy services among poor households remains low.
\end{abstract}

Keywords Developing nations $\cdot$ Human factors · Rural areas $\cdot$ Technology social factors

This material is based upon work supported by the National Science Foundation under Grant No. 0326582

J. Pal $(\bowtie)$

Center for Information and Society, University of Washington,

Seattle, WA, USA

e-mail: joyojeet@washington.edu

\section{Introduction}

Starting 2003, the state of Kerala in southern India initiated the exercise of setting up one of the world's largest mass public-use computing center kiosks throughout the $300 \mathrm{sq}$ $\mathrm{km}$ area of Malappuram, a district with a population of about 3 million residents. The district is largely rural, with the lowest human development index in the state. Although the project primarily set up telecenters through the expanse of the district of Malappuram, the initial phase of "e-literacy" involved a budget providing for one person per household trained in computer literacy over a $15 \mathrm{~h}$ training period spread through ten sessions at an Akshaya "e-Center" for Rs. 140 ( $\sim 03.50)$. The State government and the village councils together paid Rs $120(\sim \$ 3)$ towards the training, and each household paid Rs. 20 (\$ 0.50) to have one person put through the training. At the time Akshaya was originally envisioned, Malappuram was projected to be India's first completely 'e-literate' district.

Under the project, about 630 telecenters were set up to geographically ensure that, to the extent possible, no household was any more than $3 \mathrm{~km}$ walking distance away from an Akshaya e-Center. Each e-Center was meant to service approximately 1,000 families within a radius of its location, and in the e-literacy phase, a list of those assigned households was provided to each e-Center entrepreneur. Each household in the district thus had access to one eCenter where one family member could avail of training. While about two-thirds of the e-Centers were newly established businesses, about a third were pre-existing internet cafés or computer training institutes incorporated into the Akshaya brand. All new e-Centers were given subsidized agricultural rate bank loans for initial capital costs. At the end of the first phase of the Akshaya project in 2004, e-literacy 
was completed and most kiosk entrepreneurs claimed that over $90 \%$ households in their immediate vicinity had availed of the courses. About a third of the e-Centers also shut shop after the completion of the e-literacy phase. The net amount sanctioned for the Akshaya project by the government of Kerala is roughly Rs. 60 crores (US\$15 Million) per district. Part of the reason behind the selection of Malappuram as the pilot district was the high rate of migration of its work force to the Persian Gulf nations, which seemingly offered a ready market for international communication from the e-Centers using Voice over Internet Protocol (VoIP).

At the time of publication, the State of Kerala is in the process of setting up the Akshaya program in several other districts of Kerala.

\section{Previous work}

This paper builds on three major studies of the Akshaya project, each of which studied aspects of the project that help creating the case for this work

\subsection{Studies of akshaya}

The early studies of Akshaya looked at community telecenters from the point of view of State-led development, a prevalent trend in a leftist government led Kerala state (Madon and Kiran 2002; Madon 2004; Kiran 2006). The second study of Akshaya, relevant here, looked at the entrepreneur-driven aspects of the project, and the consequences of the association of a government branding with the Akshaya project. Kuriyan (Kuriyan, Toyama et al. 2006) found that association with the Akshaya project raised speculation that the typical commercial service provider would offer better quality services. This in turn affected the economic sustainability of e-Centers as viable businesses once the core engagement with the State, namely the e-literacy phase, finished. The third study took on the question as to whether the State subsidizing internet access was based on expectations that rural e-Centers would provide local populations access to information of local relevance (Nedevschi, Patra et al. 2006). That study of the Akshaya data showed that contrary to the State expectation that rural kiosks would be widely used for critical services like crop prices and e-governance, the typical kiosk user exhibited the same generalized web usage patterns as would a contemporary in the developed world.

\subsection{Work on telecenters}

In terms of overall theory of telecenters, a lot of currently existing research is guideline oriented and aimed at international agencies (Proenza and Montero 2001; Wellenius 2003); 'action oriented' research (Arunachalam 1999), telling an ethnographic story (Salvador, Sherry et al. 2005); or using telecenters to build more general ICTD theory (Roman 2003; Bailur 2006). Although some scholarly studies of telecenters (Kumar 2004) have quantified specifics of how the populace at large benefits from kiosk projects, there remains a lot we still do not know about telecenter projects.

\section{3 e-Literacy}

In terms of the e-literacy aspect of this study, there is little relevant prior scholarly work (Scott 2003; Mahmood 2005), partly because mass computer literacy projects have rarely been undertaken in the past, and even where they as in case of the traveling e-Tampere e-literacy bus (Inkinen 2006) in Finland, the context has not been one tied to ICTD.

\subsection{Key contributions}

Most scholarly work on kiosks and telecenters has started with the supply-side as the point of departure. In this case, the aim is to start at the community and take a demand-side perspective on how people perceive and use the services. This work is based on the largest household survey of families living around kiosks. The purpose of selecting random households around Akshaya e-Centers throughout the district instead of surveying people who were specifically Akshaya users was undertaken to understand from the public funding end of how the aggregated population is impacted. By using household data of actual usage, we ask whether Akshaya fulfilled the projected goal of providing widespread access, and uncover what lessons similar to subsequent implementations can gain from the Akshaya experience. The data presented questions the universal eliteracy claims of the project, and in doing so raises questions on whether e-literacy or rural telecenters are a valid form of public spending. In addition, the data offers unique insights into the marketing channels used by entrepreneurs in publicizing the e-literacy course and the telecenters. Such research is valuable in giving a better idea of the effectiveness of outreach channels for rural populations

\section{Methodology}

Although our past work with Akshaya includes both qualitative and quantitative work, this paper discusses the outcomes of the stratified survey. The results presented here include tabulations of the data of 1,750 households through the districts of Malappuram and Kozhikode in Kerala. Of these, 1,250 interviews took place in Malappuram, the experiment district where the Akshaya project was conducted by the State government. 500 households were interviewed 
from the neighboring district of Kozhikode where the Akshaya project had not been implemented. The choice of Kozhikode $^{1}$ as a control group was to have a reasonably comparable ethnic and economic make up.

\subsection{Instrument design}

A year of qualitative research in Kerala, speaking with stakeholders at the Akshaya project in 2004 formed the basis for the household survey presented here. Stakeholders interviewed included Akshaya e-center and entrepreneurs, e-center users, project managers and officers for the state government, and local politicians. A questionnaire for a household survey was prepared in early 2005 with 30 initial interviews in two iterations of 15 each held with respondents from rural Malappuram. Members of the Akshaya project team with the government of Kerala were consulted on finalizing locations for conducting the research for the final instrument, a 30-minute household survey.

\subsection{Sampling and recruitment}

The selection of respondents in Malappuram was done using a hybrid method of selecting locations based on a stratified sampling based on urbanization, status of Akshaya center, and availability of Internet connectivity. In all, 25 locations were selected, for approximately 40 interviews each, aiming for a total of about 1,000 respondents in the experimental group. One round of pre-testing of the survey instrument was done at each of the locations. Once the location was finalized, three survey takers started interviews by picking three random residential locations.

Following the first location, the interviewers counted four houses, turned next right available - and so on in concentric circles heading outwards. This approach tends to exclude outlier homes, and where relevant, the interviewers met with respondents in second-storey homes. The first adult person available at the household was interviewed; we excluded any person below 16 years of age, which is the age of consent for survey purposes in India. At each location, we aimed for 25 surveys, with some variation in what we were able to achieve. The respondent clustering and recruiting techniques used were the same for Kozhikode, though only 12 locations were selected there with approximately the same number of respondents at each location. The location selection was based on urbanization of the area and availability of Internet at the e-Center

\footnotetext{
${ }^{1}$ The main differences between Kozhikode and Malappuram were in the areas of levels of urbanization. The existence of Malappuram city, a major urban hub has important economic impact on the district, but the city's position at the edge of the two districts has meant a significant part of the extended peri-urban impact draws from Malappuram.
}

selected. After the first round of survey with the experimental group of 988 , we found that the number of respondents who had actually taken the e-literacy training was very small. Consequently, we added a booster sample of 252 e-literacy users at the end of the study using referrals from our earlier sample. This booster sample has been used primarily in making specific recommendations about learning outcomes from the program.

Finally, we also interviewed 18 e-Center entrepreneurs to triangulate the data from the survey respondents. The questionnaire for the e-Center entrepreneur was mainly on issues such as number of hours of training imparted.

\subsection{Interview process}

A team of 6 interviewers conducted the research. This included 3 male and 3 female interviewers. All interviews were conducted in Malayalam, the local language, during daylight hours on working days and on weekends. Each interview typically was about 45 minutes in length and conducted by a single interviewer. All questions were hardcoded to pre-defined criteria, based on responses estimated from the 30 pre-survey trial interviews, but an 'other' response was provided wherever relevant. For most questions, the respondents were not prompted with the multiple choice options.

\section{Findings}

\subsection{Household participation in e-literacy}

The initial surprising find for us was that less than a third of the households surveyed in the initial sample had actually any member attend the e-literacy course. We took a lot of care to ensure that the sample was adequately representative through the entire geography of the district, but at no sampled location was the e-literacy much higher than $50 \%$. General awareness of Akshaya was very high at $88.6 \%$, only $49.1 \%$ of the total sample had heard of the e-literacy program, but from those that had heard of it, over $60 \%$ had availed of it. Summing up, only $29.7 \%$ of households had any member take the course. However, in contrast, the entrepreneurs from the same locations had reported that over $90 \%$ of the households had participated in the eliteracy course by sending at least one person to train on the e-literacy module for $15 \mathrm{~h}$ at the e-Center. Several entrepreneurs reported $100 \%$ attendance, (including some from our sample), and had been paid by the State government for the same.

From the 25 locations selected, the highest percentage of households responding as having at least one member attend e-literacy was $52 \%$, and the lowest was $7.7 \%$. Assuming 
some error and variation (since the respondent and everyone else present at the house at the time of the survey could be collectively unaware of some other member of the household having taken part in e-literacy), it is still clear that the complete e-literacy claim (Bhowmick 2005)staked by the State government (Akshaya.net) is contradicted by this data.

The respondents sampled here also did not complete the entire e-literacy course of $15 \mathrm{~h}$ as prescribed. Only $14.5 \%$ from the sample of 338 e-literacy recipients had used it for a full $15 \mathrm{~h}$. A greater proportion - $18.6 \%$ - of the respondents had received only $1 \mathrm{~h}$ of e-literacy training, and the mean usage was $8.8 \mathrm{hrs}$ of e-literacy training. Furthermore, from the sample of 338 e-literacy recipients, $61.2 \%$ reported never having touched the computers themselves.

From among those who knew about the e-literacy course but chose against participating, there were a range of factors affecting their decision.

The data shows some issues with generating demand for e-literacy. Almost $50 \%$ of those who declined taking the eliteracy course felt they had more relevant things to do with their time. In addition, practically a fifth of those who did take the course never went back after the first hour of training. The second issue that stands out in the reasons for not taking the course is that of accessibility. Approximately $19 \%$ of the respondents stated discomfort with using the eCenter because of issues with the location or the entrepreneur. Village communities are complex, running enterprises there is especially tied to community relationships, which makes it important to find good neutral spaces that are seen as welcoming to all.

\subsection{Short-term impacts of e-literacy}

The 15-hour e-literacy module on an auto-run CD explains to the users certain basics about how the computer is set up and designed. This includes basic tutorials on the history of computers, the various parts of a computer, and some basic interactive tasks. The training is not geared towards making users able to use computer applications, rather it is meant to give people an introduction to computers so that they can decide later if they want to take a real computer course. Thus, computing competency is not a metric by which we judge e-literacy graduates. Instead the statistics shown on the table below are used to get an overall picture of what are the various areas where e-literacy has impacts, and to contrast some of its outcomes with other introductory computer courses. The data on computing competencies reflects a minimal overall average for Akshaya graduates. At $9.2 \%$ of the sample, using a word processor was the highest reported application that respondents used.

As we see here, the low instance of functional computer use is far from analogous to saying there was no impact of Akshaya, and seeking out immediately actionable economic impacts may be the wrong way of looking at Akshaya impacts. When the Kerala government first instituted the program, one of the key goals it had was to reduce peoples' fears of using technology, and we see from Tables 1 and 2 above that there are in fact a range of outcomes. There is clearly a drop in fear of technology and we also find in users a greater propensity towards using computers - if not for themselves, then definitely for their succeeding generations. Two items on the data suggest this. First, $30.5 \%$ of the e-literacy users felt their prestige in the village had increased because of having become 'e-literate' having now become computer literate. This was the same for the control district where people paid to get computer trained. This ties in with ideas of the aspirational discourse surrounding computers (Selwyn 2003a, b). The second item is that $9.2 \%$ of those who took e-literacy ended up signing up a child in the family for a computer class.

The comparative data with the control district of Kozhikode, shows a higher incidence of signing up children for computer classes, or even the users themselves doing another course. This is due to the respondents there being self-selectors as well as the paid computer courses being more intense than the typical Akshaya training. This supports the idea that if the users are more informed about technology and self-select to take such courses, they in fact do make decisions that continues some form of technology education in the household.

\subsection{Outreach and technology adoption}

A key contribution of the Akshaya project to other work in telecenters or rural technology adoption is its experience with outreach, since the e-literacy component technically tied the entrepreneur's income with outreach to every single household. Technically, every household from which the entrepreneur was unable to get at least one participant for eliteracy would mean a loss of a revenue of roughly $\$ 3$ that the state would otherwise guarantee the entrepreneur. The data here suggests that informal networks are an effective means of reaching potential users in rural areas. In questions around peoples' meeting spaces, we found that even in a fairly male dominated public domain, women also visited

Table 1 Reasons for not taking e-literacy course

\begin{tabular}{lr}
\hline & $\mathrm{N}=199$ \\
\hline Computers are of no use to us & $27.0 \%$ \\
Too busy to go for the training sessions & $21.0 \%$ \\
Conflict with e-Center & $19.0 \%$ \\
E-Center is too far & $9.0 \%$ \\
Neighborhood where e-Center is located is not good & $2.0 \%$ \\
\hline
\end{tabular}

$*(\alpha=0.05) * *(\alpha=0.01)$ 
Table 2 e-literacy recipients' perceptions of training benefits

\begin{tabular}{|c|c|c|}
\hline & $\begin{array}{l}\text { Malappuram e-literacy } \\
\text { recipients } \mathrm{N}=338\end{array}$ & $\begin{array}{l}\text { Kozhikode computer } \\
\text { literates }^{\partial} \mathrm{N}=49\end{array}$ \\
\hline Lost fear of computers & $95.6 \% * *$ & $72.2 \% *$ \\
\hline Understood what a computer is better & $57.4 \%$ & $70.6 \%$ \\
\hline Computer Knowledge increased respondent's respect in society & $30.5 \%$ & $54.4 \% * *$ \\
\hline Decided to study further (school or college) after experience with e-literacy & $16.9 \% *$ & $28.1 \%$ \\
\hline Signed up a child in the household for computer class & $9.2 \% *$ & $39.1 \% * *$ \\
\hline Took a subsequent course in computers & $6.5 \%$ & $32.8 \% * *$ \\
\hline Started communicating with relatives/friends using email & $0.9 \%$ & $19.6 \% * *$ \\
\hline Started using web for news and other information & $1.8 \%$ & $18.5 \% * *$ \\
\hline Saw job prospects increase due to computer knowledge & $3.3 \%$ & $26.9 \% * *$ \\
\hline Started considering working abroad after learning computer use & $1.8 \%$ & $9.7 \%$ \\
\hline Responsibilities at current work situation changed due to training & $0.6 \%$ & $10.6 \% *$ \\
\hline Contemplated changing occupation after e-literacy course & $0.0 \%$ & $2.8 \%$ \\
\hline Thought of starting a new / additional occupation or business after e-literacy & $0.0 \%$ & $0.6 \%$ \\
\hline
\end{tabular}

$* \alpha=0.05 ; * * \alpha=0.01$ (all others samples too small / not significant)

$\partial$ Kozhikode sample only includes those who got a "basic level" computer training at a private computer training institute

public spaces on a daily basis. Across both groups, bus stands $(32.4 \%)$ were the most frequented locations, and men were more likely to visit tea shops (22.4\%), more frequently. Places of religion were also an important point of congregation, though this had gender dimensions, as Muslim females were less likely to be around mosques than Hindu females were around temples.

The data on households' sources of awareness of Akshaya in Table 3 shows that direct marketing seems the most effective outreach strategy. Many entrepreneurs were

Table 3 Respondents' first source of Akshaya awareness

\begin{tabular}{|c|c|c|}
\hline & $\begin{array}{l}\text { All Randomly } \\
\text { selected homes } \\
\text { in Malappuram } \\
\mathrm{N}=875\end{array}$ & $\begin{array}{l}\text { All Households with } \\
\text { at least one e-literacy } \\
\text { participant } \mathrm{N}=531\end{array}$ \\
\hline Village Council & $13.6 \%$ & $10.4 \%$ \\
\hline Neighbors & $16.8 \%$ & $8.1 \%$ \\
\hline $\begin{array}{l}\text { Children (from } \\
\text { household) }\end{array}$ & $3.2 \%$ & $1.5 \%$ \\
\hline Friends & $4.7 \%$ & $3.6 \%$ \\
\hline $\begin{array}{l}\text { Relatives/other family } \\
\text { members }\end{array}$ & $1.8 \%$ & $1.7 \%$ \\
\hline $\begin{array}{l}\text { Akshaya e-Center } \\
\text { operator }\end{array}$ & $45.8 \%$ & $68.7 \%$ \\
\hline Government official & $3.9 \%$ & $2.4 \%$ \\
\hline TV/Radio & $1.5 \%$ & $0.4 \%$ \\
\hline Hoarding & $2.1 \%$ & $0.6 \%$ \\
\hline $\begin{array}{l}\text { Noticed Akshaya } \\
\text { E-Center }\end{array}$ & $2.9 \%$ & $1.1 \%$ \\
\hline Others & $3.0 \%$ & $0.4 \%$ \\
\hline
\end{tabular}

$*(\alpha=0.05) * *(\alpha=0.01)$, Data excludes all NR proactive about going door to door, and the data shows that this had a good pay off. We see below that home visits are significantly more effective with a multiplier of $150 \%$ ( $45.8 \%$ of the total sample first heard of the project through an entrepreneur, whereas within the sub-sample of those families that ended up taking the course, the rate was $68.7 \%$ ). The only other strategy with a 'conversion rate' of over $75 \%$ was village council meetings. While personal networks such as neighbours and friends played an important role, and clearly talking about the project mattered, the actual decision to take part in the project has strongest relationship with the visit from the entrepreneur.

While the data on word of mouth promotion of Akshaya has relevance for rural market research, we also find an interesting policy angle to the household-level decisions on projects where only one aid recipient must be chosen. The first recipient of information was not always the one who took or declined the e-literacy course. The data shows that in most cases, the decision to take part in e-literacy was one that was discussed with other household members by those who found out about the course, and in only $1.6 \%$ of the cases did one householder find out about the course and take it without consulting other householders about it. As we see in Table 4 below, the most important determinants of participation in the program are inclination and availability of an individual in the household.

This data is supported by the profile of users in the eliteracy courses. The median age of 16 years suggest that it is the school children and young adults that are most likely to use public computers in rural areas, and not adults. We could construe this information as slightly discouraging to the goals of the project to reach the most excluded citizens. 
Table 4 Household's choice on e-literacy availing member

\begin{tabular}{lr}
\hline & $\mathrm{N}=193$ \\
\hline Only person with time to do the course & $35.8 \%$ \\
Person most interested in doing it & $32.1 \%$ \\
Because they are the smartest person at home & $16.1 \%$ \\
Because he is the man of the house & $4.1 \%$ \\
Senior-most person at home & $1.6 \%$ \\
First or only person to hear about the course & $1.6 \%$ \\
\hline
\end{tabular}

$*(\alpha=0.05) * *(\alpha=0.01)$

Thus the utopian vision of the elderly and of women excluded from the work force (Scott 2003) using e-literacy is slightly weakened, but overall, it is clear that even though the users were primarily youngsters who had fairly low computer skills to begin with, and are probably more likely to be able to use the skills in the future.

\subsection{Access issues}

One of the clear benefits of the Akshaya project is that a significant of the respondents who used the computer centers at Akshaya would otherwise never have had close access to a computer. A look at column 3 in Table 5 (Malappuram Random Sample) we find that from randomly sampled individuals from across the district who we asked where they had first ever used computers, almost twice as many (8.2\%) respondents had used computers for the first time in an Akshaya center than all the remaining other means of access combined $(4.9 \%)$.

Table 1 specified some of the reasons behind people choosing not to take e-literacy and key among those was strained relationships with the kiosk owners, but other than that, there is no evidence of any exclusion of interested and needy parties from access to e-literacy. Outside of that, looking at what the points of access for people are, we find that Akshaya is playing a critical role for first access for a sizeable population in Malappuram.

The data on Table 5 shows very significant results but for a small fragment with home computer access, the majority of people start and continue to use computers at public spaces.

Three pieces of data support this. First the high proportion of Akshaya users within the sample of those that access computers in Malappuram as shown above. Second, even in the comparison group where Akshaya is not available, and ise of public access is fairly common ( $83.5 \%$ used some form of shared access through schools or computer centers). Third, those that did not avail of the e-literacy course in Malappuram tended to have much better access to computers (home, school, friends). All of these suggest that, but for Akshaya, a very large portion of the population would be denied the 'first access' to computers. To take this a step further, we can speculate that but for Akshaya, a good part of Malappuram's households would have never had their first encounter with PCs in the near future.

These three points would suggest that the telecenters are indeed playing an important role in increasing access, and depending on how the goals of telecenters are defined, this may or may not be considered a significant enough case for continued funding of such projects. If increasing the physical possibility of access to technology is the sole primary role, telecenters are clearly valuable. However, if we examine the quality and outcomes of such access, the answers are not as clear.

\subsection{Importance of entrepreneurship and e-center manager credibility}

One of the residual social goals of the Akshaya project was creating jobs by encouraging local youth and unemployed returnees from the Middle East migrant labor market to set up and manage e-Centers (Rajeev 2003). Wherever

Table 5 Location of first use/access to computers

\begin{tabular}{|c|c|c|c|c|}
\hline & $\begin{array}{l}\text { M'puram e-literacy } \\
\text { recipients (N-336) }\end{array}$ & $\begin{array}{l}\text { M'puram non e-lit. } \\
\text { recipients }(\mathrm{N}-42)\end{array}$ & $\begin{array}{l}\text { M'puram random } \\
\text { sample (N-998) }\end{array}$ & $\begin{array}{l}\text { Kozhikode Control } \\
\text { group (N-52) }\end{array}$ \\
\hline At home & $2.7 \%$ & $16.7 \% *$ & $0.9 \%$ & $2.8 \%$ \\
\hline At school & $1.2 \%$ & $19.0 \% * *$ & $1.2 \%$ & $22.4 \% *$ \\
\hline At work & $0.9 \%$ & $7.1 \%$ & $0.6 \%$ & $2.4 \%$ \\
\hline Friend's home & $1.8 \%$ & $4.8 \%$ & $0.7 \%$ & $10.6 \%$ \\
\hline At Akshaya & $89.6 \% * *$ & $4.8 \%$ & $8.2 \%{ }^{\phi}$ & - \\
\hline At a computer centre & $1.5 \%$ & $21.4 \% * *$ & $1.5 \%{ }^{\phi}$ & $41.1 \% * *$ \\
\hline NR & $2.4 \%$ & $23.8 \%$ & & $20.7 \%$ \\
\hline
\end{tabular}

$* \alpha=0.05 ; * * \alpha=0.01$ (all others samples too small / not significant)

$\Phi=$ only self-reporting respondents, not household-level data, thus not adding to $100 \%$ - only the proportions here are relevant. 
possible, locals were appointed and approved by the village Panchayats (councils) to run the e-Centers. They were not necessarily people with technical backgrounds, and several of the e-Center entrepreneurs interviewed in the course of this research were fairly new to computer use themselves. Nevertheless, in many of the Akshaya project's villages, the e-Center entrepreneur is often the first person in the village to learn the use of computers. Several of the entrepreneurs reported having found new place of pride in their communities as a result of Akshaya. To look closer at this, we included in our research design, questions as to whom the local residents turned to for technical questions.

Extensive work by Kuriyan (Kuriyan, Toyama et al. 2006) has focused on the effects of State branding, as well as outreach efforts on the Akshaya telecenter entrepreneur's effectiveness as well as peoples' perceptions of them. In attempting to extend this work, our pre-survey research included interviews of both the entrepreneurs and residents of Malappuram on issues of 'technical credibility' of Akshaya. From the data here, we assessed that the combination of the non-market approach to choosing the eCenter, the entrepreneur and the consequent State branding of the project seem to have all played a part in impacting the credibility of the e-Center entrepreneur.

While the Akshaya entrepreneur in some places became a 'new authority' on computers in the villages, doubling up the e-Center business with a computer sales business on the side, in others, the e-Center had to contend with comparison to an existing and well respected computer training center. We asked people who they turned to for advice on things like taking computer classes or buying computers, the outcomes of which we see in Table 6 and 7.

While in Kozhikode, the local computer training institute manager is clearly the most important contributor to decisions around computer training courses or decisions to purchase computers, the same is not true for Malappuram where there is less than a fourth of what we see in Kozhikode in terms of faith invested in the Akshaya entrepreneur for

Table 6 First/preferred source of information on technology

\begin{tabular}{llc}
\hline & $\begin{array}{l}\text { Malappuram } \\
\mathrm{N}=531\end{array}$ & $\begin{array}{l}\text { Kozhikode } \\
\mathrm{N}=136\end{array}$ \\
\hline School Teacher & $29.6 \% * *$ & $15.1 \% *$ \\
Akshaya Manager / Other & $10 . \%^{*}$ & $41.7 \% * *$ \\
$\begin{array}{l}\text { Telecenter Manager } \\
\text { Friend }\end{array}$ & $31.8 \%^{* *}$ & $3.2 \%$ \\
$\begin{array}{l}\text { Other Computer-related worker / } \\
\text { business }\end{array}$ & $14.3 \%$ & $12.9 \%$ \\
Consult nobody & $7.1 \% * *$ & $0.7 \%$ \\
\hline
\end{tabular}

${ }^{*} \alpha=0.05 ;{ }^{*} \alpha=0.01$ (all others samples too small / not significant)

$\mathrm{N}=$ every respondent household with at least one computer trained person Only top 5 responses showed here such decisions. The key local authority for such decisions remains the school teacher, as seen in other research (Lottie 1975), and a fairly large class of persons in both locations turned to teachers for advice. Personal networks such as friends played a much less important role in consultation in Kozhikode than in Malappuram, where a fairly sizeable population felt there was really nobody they could consult on such decisions. On the whole, the data showed that the typical Akshaya entrepreneur supports strong ethnographic research that being a 'State appointee' rather than a selfmade businessman with technical credentials had a negative impact on the credibility of these entrepreneurs. In all, 12 of the 18 e-Center entrepreneurs interviewed had no computer use experience before Akshaya, and 3 others were able to use office applications. However, there was no clear correspondence between prior computer use experience and an entrepreneur's success.

On the issue of credibility of the e-Center entrepreneur, the data shows a fairly wide gap between what the entrepreneurs reported as their e-literacy achievements and what the data from the respondents in those geographical areas suggested. The data used here is the entrepreneurs' responses for what proportion of local households they trained for e-literacy (and got paid for by the government), vis-à-vis the corresponding data from the responses from households.

The most surprising facet of this data is that from the 6 cases of entrepreneurs who shut shop after the e-literacy completion, 5 are those with the highest discrepancies (codes 2206, 1206, 3207, 3224 and 2207) between their claim of how many people trained for e-literacy at their eCenters, and what proportion of the households responded as having participated in the scheme. While this is not conclusive evidence, there is clear cause for further examination of the practices of many of the entrepreneurs with regard to e-literacy provision.

\section{Analysis}

As a preface to the analysis of the tables presented above, it is useful to run through the current status of the Akshaya project. The Kerala government has started rolling out the project in seven districts of the State. To the credit of the State, it has been proactive about learning from the pilot phase in Malappuram and has changed several features of the second phase accordingly. The first and most important change has been slimming down the program from roughly one e-Center per 1,000 households to about one per 3000 , significantly reducing its costs. In 2007, about 1,600 Akshaya centers are operational in eight districts of Kerala, and another 1,173 e-Centers have been finalized for further deployment in the next seven districts earmarked in Kerala. The beneficiary household's contribution to the e-literacy 
Table 7 Entrepreneur-reported e-literacy compared to survey e-literacy reporting
*Figures as reported to us during our survey, not as per claims filed with the IT mission at the government of Kerala

\begin{tabular}{|c|c|c|c|c|}
\hline \multirow[t]{2}{*}{ e-Center Code (n) } & \multicolumn{2}{|c|}{ Survey Respondents' Figures } & \multicolumn{2}{|c|}{ Entrepreneur's Figures * } \\
\hline & e-literacy awareness & e-literacy taken & e-literacy taken & Data discrepancy \\
\hline $2205(40)$ & $47.5 \%$ & $45.0 \%$ & $68.3 \%$ & $23.3 \%$ \\
\hline $2204(40)$ & $62.5 \%$ & $40.0 \%$ & $66.7 \%$ & $26.7 \%$ \\
\hline $1105(40)$ & $70.0 \%$ & $22.5 \%$ & $65.2 \%$ & $42.7 \%$ \\
\hline $3218(40)$ & $27.5 \%$ & $15.0 \%$ & $58.9 \%$ & $43.9 \%$ \\
\hline $2102(52)$ & $53.8 \%$ & $28.9 \%$ & $74.2 \%$ & $45.3 \%$ \\
\hline $3104(28)$ & $78.6 \%$ & $42.9 \%$ & $88.7 \%$ & $45.8 \%$ \\
\hline $2203(40)$ & $57.5 \%$ & $27.5 \%$ & $74.3 \%$ & $46.8 \%$ \\
\hline $1103(41)$ & $41.5 \%$ & $12.2 \%$ & $58.8 \%$ & $46.6 \%$ \\
\hline $2103(40)$ & $65.0 \%$ & $50.0 \%$ & $100.0 \%$ & $50.0 \%$ \\
\hline $2202(40)$ & $47.5 \%$ & $25.0 \%$ & $76.0 \%$ & $51.0 \%$ \\
\hline $3105(41)$ & $51.2 \%$ & $31.7 \%$ & $83.5 \%$ & $51.8 \%$ \\
\hline $1207(40)$ & $60.0 \%$ & $27.5 \%$ & $83.3 \%$ & $55.8 \%$ \\
\hline $1204(40)$ & $50.0 \%$ & $42.5 \%$ & $100.0 \%$ & $57.5 \%$ \\
\hline $2206(40)$ & $42.5 \%$ & $15.0 \%$ & $76.0 \%$ & $61.0 \%$ \\
\hline $1206(39)$ & $20.5 \%$ & $20.5 \%$ & $89.6 \%$ & $69.1 \%$ \\
\hline 3207 (26) & $26.9 \%$ & $7.7 \%$ & $80.0 \%$ & $72.3 \%$ \\
\hline $3224(40)$ & $82.5 \%$ & $27.5 \%$ & $100.0 \%$ & $72.5 \%$ \\
\hline 2207 (33) & $30.3 \%$ & $18.2 \%$ & $100.0 \%$ & $81.8 \%$ \\
\hline
\end{tabular}

course has been doubled, to increase the e-Centers answerability directly to the people. The project now has a number of functional services including e-vidya for computer training, e-pay for bill payment. ${ }^{2}$ Interestingly, this next phase of the project has created no new e-centers, only co-opted existing cybercafés into the Akshaya network.

More recently, the Akshaya project was in the news because of a symbolic protest by Malappuram's e-center entrepreneurs who took to the streets with begging bowls soliciting small change to help pay off the debt accumulated during their involvement with the project.

\subsection{E-literacy delivery through fixed telecenters}

Despite the gaps in universalization of e-literacy, it is clear that but for the Akshaya project, a large portion of the population would never have had close quarters experiences with technology. The question then becomes, if eliteracy is the goal, is the setting up of fixed infrastructure of telecenters the best means of delivery?

The original idea behind having the fixed infrastructure of telecenters was to create a network of access - such that after the initial exposure to e-literacy, citizens could turn to a location near their homes to use computer centers either to get further computer training or access the internet. However, the data shows that the typical 'e-literacy' recipient is not the

\footnotetext{
${ }^{2}$ At the time of this survey, e-pay was not fully functional, therefore the data collected here gives a skewed view of the project
}

one using the Akshaya centers on a continuous basis. The mean age of those that had used Akshaya at any point according to the survey was 25.8 yrs, but conversations with e-center owners indicated that they typically expected to make their income from young college or high school students browsing or enrolled in online classes. As far as service delivery for this segment goes - the Akshaya e-Centers do not really provide web surfing services at rates much lower than that of the open market. With regard to the other major use of kiosks, that of training, the typical Akshaya entrepreneur tends to be less technically trained than a typical selfstarter entrepreneur running a computer center as we saw in our own sample. Thus, the Akshaya entrepreneur stands at a disadvantage against the self selecting computer training entrepreneur. Once the e-literacy phase is done, the e-Center is really thrown to market forces, with perhaps just the slight advantage of free connectivity courtesy of the government, and some subsidies in capital expenditure. Thus the challenges of open market competition are clearly evidenced in the fact that most of the best performing e-Centers tend to be those that were already independent computer centers before the Akshaya project started, and joined the fold to take part in the e-literacy and avail of the branding benefits. Not surprisingly, very few of those Akshaya centers that shut down were pre-existing computer centers, and a large number of casualties were those that were unable to compete after the e-literacy phase with government-subsidy was over. From our own sample, 6 out of the 18 entrepreneurs had shut shop but were willing to speak, though the remaining 7 from a sample 
of 25 were in varying stages of scaling back their businesses. Another 3 of the 6 cases that had shut shop competed with another computer center in the immediate vicinity.

Therefore, if providing e-literacy is the main goal for the government, delivery through newly established e-Centers is unnecessarily expensive and self-defeating. It is possible to examine several other models attempted in the past. One is the Finnish eTampere case; another could be is the use of school buildings with makeshift computer centers. (Inkinen 2008)

\subsection{Target group demography}

The evidence presented in this paper makes a case for orienting rural telecenters towards providing services for rural children and youth rather than for adults. There is evidence that content tailor-made for rural adults is not used, that orienting rural telecenters around crop price and other agriculture oriented projects tend to work only around supply chain relationships (Kumar 2004), that e-governance by itself is not adequate to make rural kiosks work and finally that bringing outdated urban technology into rural low-income spaces plays a role in creating resentment and possibly alienating potential users (Ferraz, Fonseca et al. 2004). Children do not have to be sold on the idea of using a technology (for instance, the highest reason for not taking e-literacy was 'no use of computers' a response that came only from adults in their $30 \mathrm{~s}$ and above). Children also tend not to feel threatened by using technology unlike adults, who often need a concrete use for technology before agreeing to be users. The data shows that one of the strong positive impacts of Akshaya has been that over $50 \%$ of the recipients of e-literacy talk about their experiences using computers with members of their households. It is worth starting discussions on whether this can be leveraged positively by creating assignments for school students to train household members or by using college students to do barefoot campaigns.

The research in Malappuram also raises some questions about the validity of an argument for more telecenters based on the lack of physical access. A number of telecenters did in fact bring computers for the first time into the villages where they were established, but given that the project and the e-literacy was aimed at the household as a unit, it is interesting to note that $73.2 \%$ of all households had at least one child with access to computers in school (higher than the Figs 1 and 2 for the neighbouring district of Kozhikode at 64.5). If the case for building new telecenter still stands despite children's access from within households, one potential way to think ahead would be whether the infrastructure at school computer centers can be used to double up as telecenters, an approach tried in Andhra Pradesh in the past (Martyris 2003).

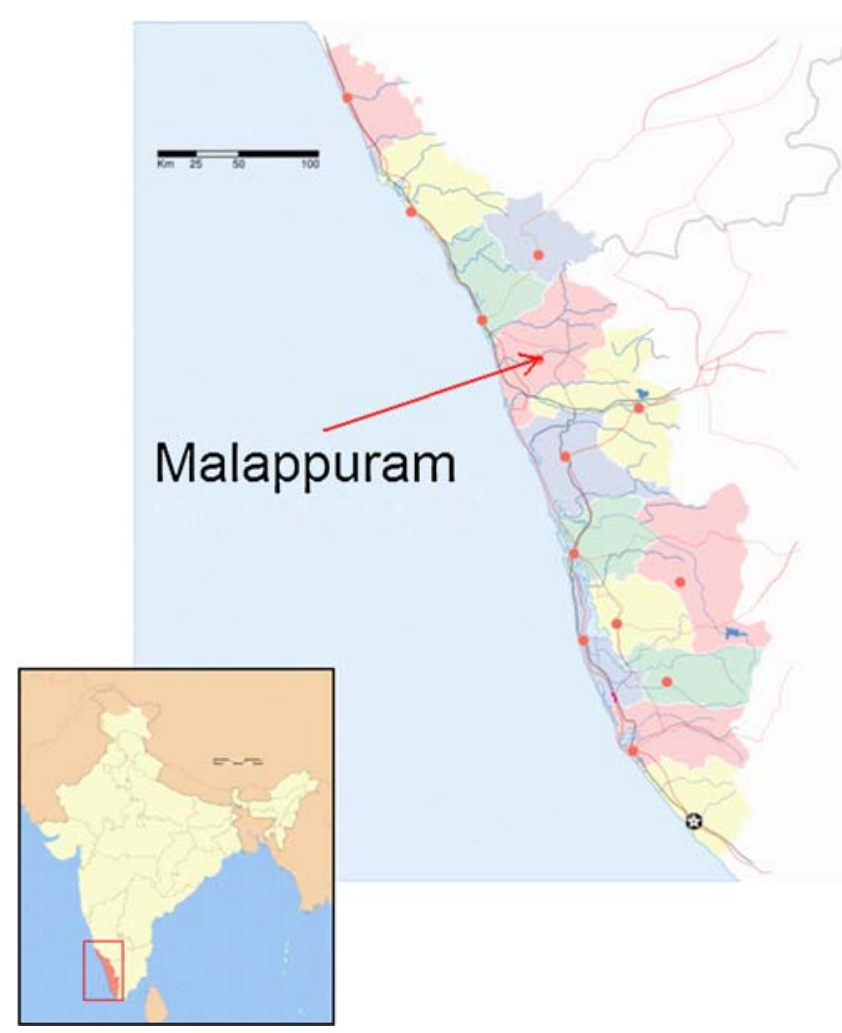

Fig. 1 Map locating Malappuram within Kerala, India. (Map source: Wikimedia Commons)

\subsection{Political considerations}

Declaring a village or block e-literate has come to symbolize a form of technology-led development in Kerala. Periodically, such proclamations of $100 \%$ e-literacy for a village are done in the presence of political dignitaries, and such events receive a lot of press coverage. Data collected in the survey on peoples' participation on the political discussions over funding Akshaya presents an interesting perspective on the participative nature of decision making in Akshaya. It is no coincidence that the Malappuram district was the home constituency of the Information Technology Minister P. Kunhalikutty at the time of Akshaya's original deployment in the early $2000 \mathrm{~s}$.

The Akshaya project was frequently touted as being a bottom-up project since the funding for it came from the village councils. However, our data shows that only $1.7 \%$ of the households interviewed were aware of Panchayat meetings for funding Akshaya and council funds being used for e-literacy. While such a lack of local level control is frequently true for state-level spending, Panchayat funding tends to be closely monitored. The Akshaya project also was structured around a few charismatic and competent project champions (Madon 2005), and this as a pattern is seen in a number of telecenter projects (Curtain 2004). The aspect of declaring places 'e-literate' has become an important proxy for development. That said, the involve- 


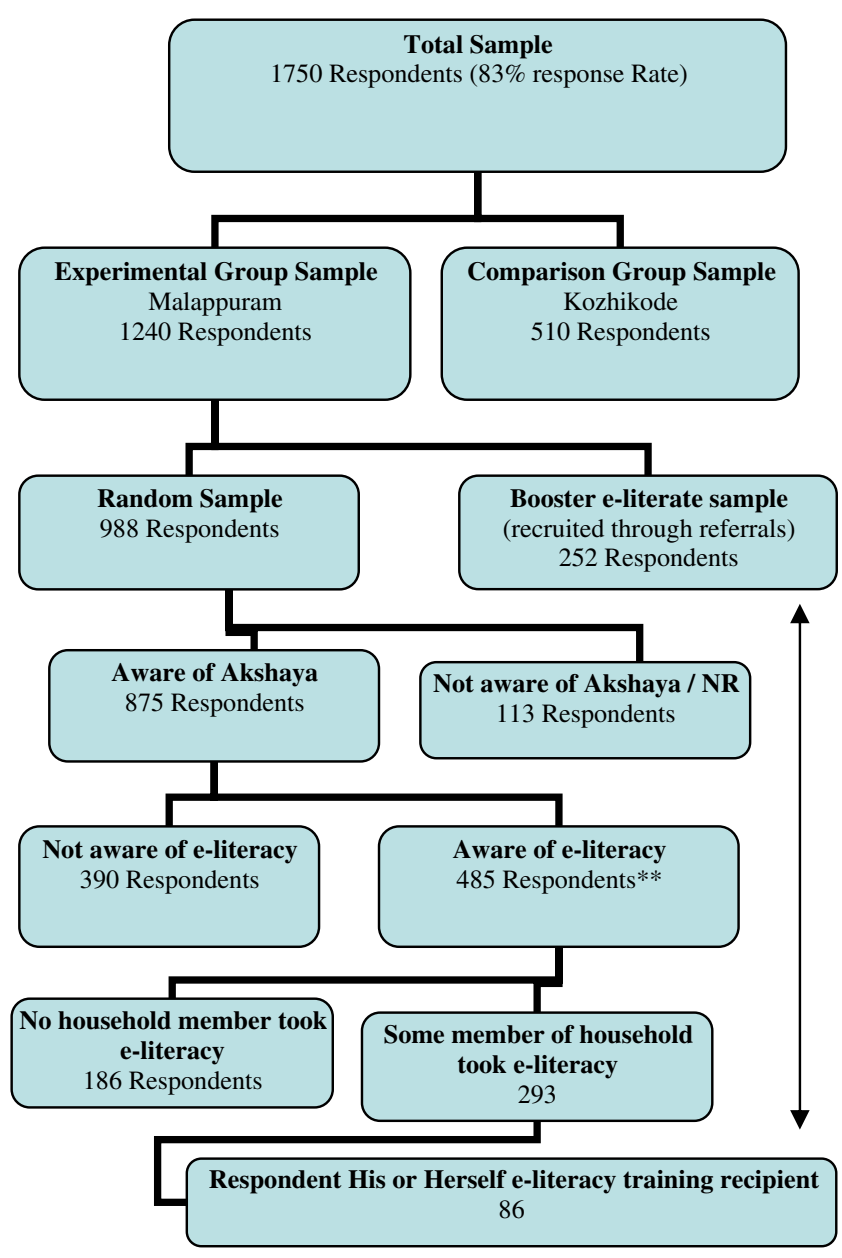

Fig. 2 Sample Description. *Vertical arrow connects the "e-literates" portion of the total respondent sample. ${ }^{* *}$ Some NR responses explain gaps in the data

ment of Kunhalikutty played a charismatic role in getting the project off the ground, moving quickly past a complicated political and bureaucratic structure (including the transfer as collector to Malappuram a leading officer and visionary in the Kerala IT mission), and it is quite likely that without his strong support, the e-Centers may never have been deployed, certainly not on the express speed with which they made it to the market. Kuriyan rightly finds important political considerations around the establishment and day-to-day running of the Akshaya project, and this alongside the idea of political currency from ICTD projects is certainly an angle that needs more examination in the future. (Kuriyan, Toyama et al. 2006).

\subsection{Sustainability and the question of privatization}

The data indicates that the overall use of computer center facilities is itself on the low side. Only $2.7 \%$ of the randomly selected respondents knew of the e-Centers being used in the past week. Of these, $2.4 \%$ had used the e-Center for bill payment rather than for any internet or training facility. Surprisingly, there was little evidence of use of international communications services using VoIP calls or instant messaging, one of the major assumed uses of the e-Centers. The data suggests that in several parts of Malappuram, running a profitable cybercafé or computer training business could be difficult, regardless of the existence of migrants in households and the corresponding needs for communication. In short, the conversion from a State-supported Akshaya model to a sustainable private business can present significant challenges.

The question of sustainability has always been a complex one for Akshaya. Proponents of the economic sustainability view find that success or failure of an Akshaya e-Center depends on an individual entrepreneur's ability to keep the center alive as a business after the initial push by the government. On the other hand, it is clear that in a large number of locations, the e-Centers are highly unlikely to be economically viable given the lack of local capacity to support them. The State government's phasing out of 'unsustainable' business is reflected in the scaling down of the project to about 1 center to 3,000 families. The experience from Malappuram is adequate evidence to either uncouple the sustainability-public service mix, or invent new business models to ensure viable businesses while protecting consumers.

\subsection{Checks and balances}

If a large number of people have not received training, how has the government paid entrepreneurs? The issue is twofold. First, at the supply end, more thought needs to be put into whether the current means of delivery adequately ensures that people who are meant to get the service actually do get it. There are technological ways of doing this (Nedevschi, Patra et al. 2006) as well as means of creating social responsibility around entrepreneurs. The more desirable approach would be if people themselves felt vested in the e-literacy as they do perhaps for issues like mid-day meals or free uniforms in various parts of the State, where one would contend with a riot should the pledged public service not be provided. In Malappuram, it is clear that a large number of people knew that their 'e-literacy' was not being provided, and irrespective of whether they felt the entrepreneur should benefit from it, there is little doubt that few were outraged enough to demand it as a right. For this to happen, the demand for e-literacy has to truly come from below.

\section{Conclusions}

The conclusions about e-literacy in specific regard to Akshaya are fairly definitive, the services did not reach 
nearly as many people as was intended, and even those that it did reach did not opt for the free computer training offered.

But whether we can make broader claims based on this data is not as clear. A vital finding of this research was that a relationship existed between low e-literacy uptake and profiteering by certain entrepreneurs. This factor in itself dilutes any claim of generalizability of these findings as reliable indicators of peoples' actual participation in eliteracy. Secondly, this data also makes it clear that the eliteracy training material did little to find people jobs, including those that went through the entire $15 \mathrm{hr}$ package. Although this may not have been part of the goal, other studies have shown that the actual participants in computer education projects frequently tend to be driven by hopes of eventual financial gain rather than learning for learning's sake (Ferraz 2004). Our inference that personal motivations based on factors such as reducing fear of computers fell quickly (presumably after the first few classes the fear is gone) is supported by the high percentage of early dropouts from the e-literacy course.

It is also clear that for a large number of people in the sample, without Akshaya they would quite probably never have had used a computer in their lives, irrespective of what they may choose to do with the machine. While our data analysis shows results counter to the goals of Akshaya's mission, overall, on the issue of 'continued use' of telecenters by citizens, it is clear that even the slightly lower prices often offered by Akshaya centers for computer training courses are highly valued even if respondents were not necessarily overly enthusiastic about enrolling for such classes. For a simple statistic, we found that $28.7 \%$ of the sample were aware of some private computer center in their immediate vicinity other than Akshaya, but only $11.4 \%$ of the sample felt these were affordably priced.

In returning here to the question posed in the title: If the State provided free computer literacy, would it find takers? - well, unfortunately we don't have a definitive answer. We do know that in Kerala, e-literacy did not find takers, but we also know that the delivery and content were themselves deeply flawed.

That said, the general case made here still tilts against providing services like e-literacy, or telecenters generally. The model of the Akshaya project to artificially jump-start businesses and support them through e-literacy seems to have served neither purpose. A large number of the businesses shut shop right after the e-literacy phase was over, and from those that survive now, a significant number were already cybercafés before they joined the Akshaya fold and simply changed their branding. In fact, taking cue from that finding, the government of Kerala, probably one of the most courageous investors in the ICTD space so far, decided to abandon the practice of setting up Akshaya e-centers for the rest of the state after the Malappuram pilot. The larger deployment of Akshaya through the rest of the state simply identifies existing cybercafés and gives them the Akshaya brand with the accompanying e-literacy underwriting. While this in itself signals a strong statement against state funding of telecenters, it doesn't help us answer the question of whether e-literacy is itself a valuable state-provided service. The nature of the question makes it hard to answer in the short-term, though we know for certain that without a curriculum that users feel is strong enough to help get them jobs, the buy-in is limited, and consequently, the recipients of the technology have very little interest in making sure that they get the training from the people that the government paid to train them. If a single factor had to be cited as the greatest challenge of the Akshaya project, it would probably be that there was never any real buy-in from the people it was meant to serve.

Acknowledgments Thanks to Eric Brewer and the UC Berkeley TIER project for consistent support of this project and also to Sergiu Nedevschi, Rabin Patra, Kentaro Toyama and Renee Kuriyan for discussions around the issue.. Special thanks to G.R. Kiran and the fabulous Akshaya team including MS Vinod and Rahman. Thanks also to Lalitha, R. Ashok, and Praveena of Kaybase Chennai, and the survey team. Finally many thanks to the 5 blind reviewers and editorial team led by Balaji Parthasarathy and Krithi Ramamritham for their input in making this a better read.

Open Access This article is distributed under the terms of the Creative Commons Attribution Noncommercial License which permits any noncommercial use, distribution, and reproduction in any medium, provided the original author(s) and source are credited.

\section{References}

Arunachalam, S. (1999). Information and knowledge in the age of electronic communication: a developing country perspective. Journal of Information Science, 25(6), 465.

Bailur, S. (2006). Using Stakeholder Theory to Analyze Telecenter Projects. Information Technologies and International Development, 3(3), 61-80.

Bhowmick, S. (2005). Malappuram, India's 1st e-literate district. Rediff.com.

Curtain, R. (2004). "Information and communications technologies and development: Help or hindrance." AusAID Virtual Colombo Plan.

Ferraz, C., R. Fonseca, et al. (2004). Computing for Social Inclusion in Brazil: A Study of the CDI and Other Initiatives. First UCBUNIDO Bridging the Divide Conference. (2004). Berkeley. UNIDO: CA.

Inkinen, T. (2006). The Social Construction of the Urban Use of Information Technology: The Case of Tampere, Finland. Journal of Urban Technology, 13(3), 49-75.

Inkinen, T. (2008). Challenges to Digital Governance: Perspectives on E-lnclusion in Tampere, Finland. Creative Urban Regions: Harnessing Urban Technologies to Support Knowledge City Initiatives. T. Yigitcanlar, K. Velibeyoglu and S. Baum: 148164. 
Kiran, G. R. (2006). E-governance services through Telecentres-Role of Human Intermediary and issues of Trust. Information and Communication Technologies and Development, 2006. ICTD '06.

Kumar, R. (2004). eChoupals: A Study on the Financial Sustainability of Village Internet Centers in Rural Madhya Pradesh. Information Technologies and International Development, 2(1), 45-74.

Kuriyan, R., K. Toyama, et al. (2006). "Integrating Social Development and Financial Sustainability: The Challenges of Rural Computer Kiosks in Kerala." Information and Communication Technologies and Development, 2006. ICTD'06. International Conference on: 121-130.

Lottie, D. (1975). Schoolteacher: A Sociological Study. Chicago: University of Chicago.

Madon, S. (2004). Evaluating the Developmental Impact of eGovernance Initiatives: An Exploratory Framework. EJISDC, 20(5), 1-13.

Madon, S. (2005). Governance lessons from the experience of telecentres in Kerala. European Journal of Information Systems, 14(4), 401-416.

Madon, S. and G. R. Kiran (2002). "Information Technology for Citizen-Government Interface: A Study of FRIENDS Project in Kerala." World Bank Global Knowledge Sharing Program (GKSP). Available at: www1. worldbank. org/publicsector/ bnpp/egovupdate. htm.

Mahmood, K. (2005). Multipurpose community telecenters for rural development in Pakistan. The Electronic Library, 23(2), 204-220.

Martyris, D. (2003). Community-Government partnerships and open source technology for low cost IT access in India-A case study, July.

Nedevschi, S., Patra, R., et al. (2006). A Multidisciplinary Approach to Studying Village Internet Kiosk Initiatives: The Case of Akshaya. E-Learning, 3(3), 291-316.
Proenza, F., \& Montero, R. (2001). Telecenters for socioeconomic and rural Development. . Working Papers: Inter American Development Bank.

Rajeev, K. (2003). Young entrepreneurs make good of Akshaya eliteracy programme. Thiruvananthapuram: The New Indian Express.

Roman, R. (2003). Diffusion of Innovations as a Theoretical Framework for Telecenters. Information Technologies and International Development, 1(2), 53-66.

Salvador, T., Sherry, J. W., et al. (2005). Less cyber, more cafe: Enhancing existing small businesses across the digital divide with ICTs. Information Technology for Development, 11(1), 7795.

Scott, E. S. (2003). Computer-based functional literacy: How digital literacy projects can transform the third-world workforce. Professional Communication Conference (IPCC 2003) IEEE Proceedings.

Selwyn, N. (2003a). Apart from technology: understanding people's non-use of information and communication technologies in everyday life. Technology in Society, 25(1), 99-116.

Selwyn, N. (2003b). "Doing IT for the Kids': Re-examining Children, Computers and theInformation Society'." Media. Culture \& Society, 25(3), 351.

Wellenius, B. (2003). "Sustainable Telecenters: A Guide for Government Policy." The World Bank Group, Private Sector and Infrastructure Network, Note 251.

Joyojeet Pal is a Research Associate at the Center for Information and Society at the University of Washington. His recent research is primarily in the aspirational environment around technology projects in the developing world. 